\title{
Lung cancer incidence trends in Świętokrzyskie Voivodeship in 1999-2013
}

\section{Trendy zachorowalności na raka płuca w województwie świętokrzyskim w latach 1999-2013}

\author{
Paweł Macek ${ }^{1,2}$, Piotr Matuszewski ${ }^{3}$, Ewa A. Błaszkiewicz ${ }^{1,4}$, Małgorzata Biskup ${ }^{5,6}$, Monika Nogajczyk ${ }^{1}$, \\ Anna Lipińska ${ }^{5,7}$, Leszek Smorąg ${ }^{1,8}$, Stanisław Góźdź9,10
}

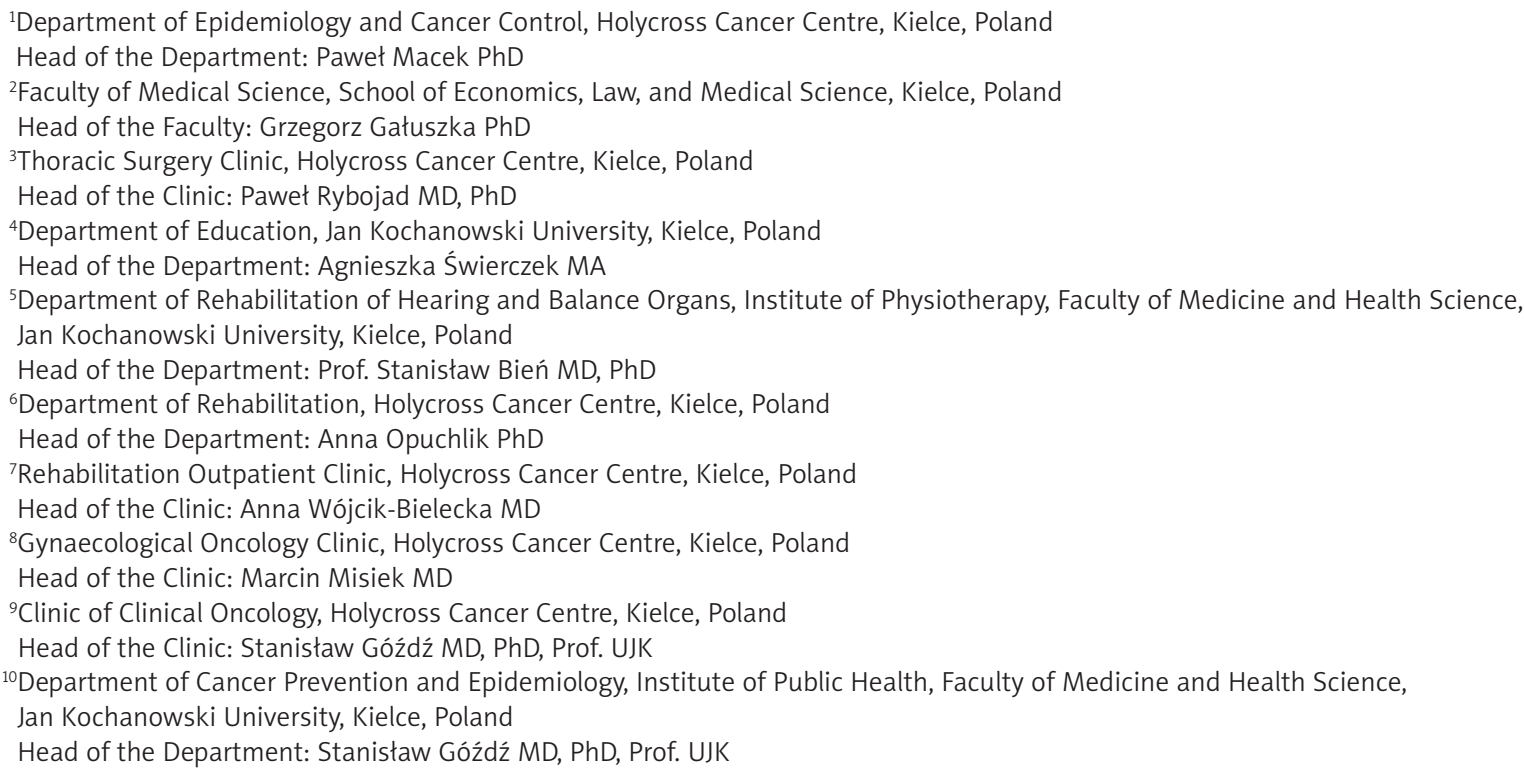

Key words: lung cancer, incidence trends, epidemiology, Świętokrzyskie Voivodeship.

Słowa kluczowe: rak płuca, trendy zachorowalności, epiemiologia, województwo świętokrzyskie.

\begin{abstract}
Introduction: Lung cancer is the most common malignant cancer worldwide. In 2013 a total of 21,524 new cases of lung cancer in Poland and 751 (576 in men and 175 in women, respectively) in Świętokrzyskie Voivodeship were reported.

Aim of the research: To assess the dynamics of changes in lung cancer incidence between 1999 and 2013 in the population of inhabitants of Świętokrzyskie Voivodeship by sex.

Material and methods: Eleven thousand four hundred and eighteen new lung cancer cases in Świętokrzyskie Voivodeship in 1999-2013 were analysed. Crude rates (CRs) and age-standardised rates (ASRs) per 105 population were calculated, in general and by sex. The analysis of incidence trends was carried out using joinpoint models.

Results: In 2013 a significant decrease by $22.3 \%$ in lung cancer incidence was reported in comparison with the year 1999. A significant decrease by $32.3 \%$ among men and non-significant increase by $32.3 \%$ in lung cancer incidence among women were reported. The relative risk of lung cancer incidence in men decreased by $44.5 \%$ compared to women. The trend in ASRs showed a significant decrease by $2.0 \%$ per year. In the male population a significant decreasing trend by $2.9 \%$ per year and a significant increasing trend by $2.1 \%$ per year among the female population were observed. The lung cancer incidence among men in Świętokrzyskie Voivodeship decreased, with a simultaneous increase in incidence among women in 1999-2013. Sex was the main factor that differentiated the shaping of incidence trends. A significant decreasing incidence trend among men and a significant increasing incidence trend among women were observed.
\end{abstract}

Conclusions: It is necessary to intensify the primary and secondary prevention of lung cancer in the voivodeship. 


\section{Streszczenie}

Wprowadzenie: Rak płuca jest najczęstszym nowotworem złośliwym na świecie. W Polsce w 2013 r. zarejestrowano 21524 nowych zachorowań. W województwie świętokrzyskim odnotowano 751 nowych zachorowań (576 u mężczyzn i 175 u kobiet). Cel pracy: Określenie dynamiki zmian zachorowalności na raka płuca w latach 1999-2013 u mieszkańców województwa świętokrzyskiego z uwzględnieniem płci.

Materiał i metody: Analizie poddano 11418 zachorowań na raka płuca w województwie świętokrzyskim w latach 1999_ 2013. Obliczono surowe i standaryzowane współczynniki zachorowalności, wyrażone na $100000\left(10^{5}\right)$ populacji, łącznie i z podziałem wg płci. Analizę trendów zachorowalności przeprowadzono za pomocą modeli joinpoint.

Wyniki: W 2013 r. w porównaniu z 1999 r. w województwie świętokrzyskim odnotowano istotną redukcję zachorowalności na raka płuca o 22,3\%. U mężczyzn obserwowano istotne zmniejszenie zachorowalności o 32,3\%, a u kobiet nieistotny wzrost zachorowalności o 32,3\%. Ryzyko względne zachorowania na raka płuca u mężczyzn w porównaniu z kobietami zmniejszyło się o 44,5\%. U mężczyzn stwierdzono istotny trend spadkowy w tempie 2,9\% rocznie, a u kobiet istotny trend wzrostowy w tempie 2,1\% rocznie. W województwie świętokrzyskim w latach 1999-2013 obserwowano redukcję zachorowalności na raka płuca u mężczyzn oraz wzrost zachorowalności u kobiet. Płeć różnicowała też kształtowanie się trendów zachorowalności. U mężczyzn stwierdzono istotny spadek trendu, a u kobiet istotny jego wzrost.

Wnioski: Konieczna jest intensyfikacja działań w zakresie pierwotnej i wtórnej profilaktyki raka płuca w województwie.

\section{Introduction}

Lung cancer is the most common malignant cancer worldwide according to the International Agency for Research on Cancer. In 2012, 1.8 million new cases were registered (1.2 million among men and 0.6 million in women, respectively). In the structure of malignant cancer incidence, lung cancer comprised $12.9 \%$ (16.7\% among men and 8.8\% in women, respectively) [1]. In Europe 410,000 new cases were reported (219,000 in men and 119,000 in women, respectively) [2]. In Poland, according to the National Cancer Registry, 21,524 new cases were reported $(14,609$ in men and 6915 in women, respectively) in 2013 [3]. In Świętokrzyskie Voivodeship, according to data from the Holycross Office of Cancer Registration, in 2013 a total of 751 new lung cancer cases were reported (576 in men and 175 in women, respectively) [4].

\section{Aim of the research}

The aim of the study was to assess the dynamics of changes in lung cancer incidence between 1999 and 2013 in the population of inhabitants of Świętokrzyskie Voivodeship by sex.

\section{Material and methods}

\section{The field and the design of the study}

Lung cancer was the most common cancer in men and the fourth most common cancer in women in Świętokrzyskie Voivodeship in 2013. In the structure of cancer incidence in men and women, lung cancer comprised $20.4 \%$ and $6.7 \%$, respectively.

\section{Data sources}

The authors obtained information regarding 11,418 new lung cancer cases (9170 in men and 2248 in women) in Świętokrzyskie Voivodeship between 1999 and 2013. The mean age at diagnosis of lung cancer was 66.0 (range: $16-97$ ) years for men and 66.2 (range: 23-96) years for women. Data, which were recorded in Cancer Registration Forms (Mz/N-1a), were obtained from Holycross Office of Cancer Registration in Kielce. Data were collected in accordance with the Public Statistics Act from 29 June 1995 (Journal of Laws No88, position 439 with further amendments). The analysis included information on lung cancer cases (C34) coded according to the International Statistical Classification of Diseases and Related Health Problems ICD-10. The data regarding the population of Świętokrzyskie Voivodeship according to actual place of residence on June 30, in general and in eighteen five-year age groups, starting from the age of 0 to 85 years and older, separately for men and women, were obtained from the Statistical Office in Kielce.

\section{Statistical analysis}

The crude rates, age-specific, and age-standardised incidence rates per $100,000\left(10^{5}\right)$ population were calculated separately for men and women and in total. Standardisation of incidence rates was carried out using a direct method taking the World Standard Population as a reference, in accordance with IARC/WHO guidelines. The population burden of lung cancer was shown as a percentage. The percentage change for the absolute number of new cases was calculated along with the values for crude and age-standardised incidence rates and the percentage of population burden of lung cancer based on border years of analysis.

The significance of the assessed parameters was evaluated using Z-statistic. In case of $|Z|>1.96$, a change in value of the assessed parameter was considered significant for $\alpha=0.05$. The standard errors for crude and age-standardised incidence rates were calculated, respectively [5]. Excess incidence in the male population was calculated compared to the female population [6]. The analysis of incidence time trends was carried out using joinpoint models. This 
method is an extension of simple linear regression to a model, in which the plot of trend function is shown as a polygonal chain consisting of segments joined with one another at points (joinpoints), in which significant changes in the linear trend slope were observed for $\alpha=0.05$. The annual percentage changes (APC) in incidence rates for lines showing time trends with their respective confidence intervals (CIs) were calculated. Trends for incidence rates among men and women were compared using the Test for Parallelism. APC values $\leq-1.0 \%$ or $\geq 1.0 \%$ showed a downward or an upward trend, respectively. The APC values, satisfying the condition APC $>-1.0 \%$ and APC $<1.0 \%$ showed a stable trend. The statistical analysis as well as the graphic interpretation of results were carried out using Microsoft Office, SAS Enterprise Guide, and Joinpoint Regression Program version 4.2.0.2 software, licensed to Holycross Cancer Centre in Kielce.

\section{Results}

In 2013, a decrease of $5.7 \%(\Delta=-45)$ in the absolute number of new lung cancer cases was noted in com- parison to the year 1999. The percentage of population burden of lung cancer was decreased by $1.7 \%$. A nonsignificant decrease of $1.7 \%$ was noted based on the crude incidence values; however, after standardisation of rates the decrease was significant and was 23.3\% $(p<0.05)$. Changes in the absolute number of new cases in the male and female populations were opposite. In the male population a decrease of $15.6 \%$ was noted $(N=106)$, whereas in the female population the number of new cases increased by $53.5 \%(N=61)$. Changes in the percentage of population burden of lung cancer in men and women were of the opposite direction. In the male population, the decrease in population burdened with lung cancer was $11.5 \%$, but in the female population an increase of $59.2 \%$ was seen. The opposite tendencies in analysed populations were visible in the changes in incidence rate values as well. The significant decrease in incidence in men based on crude and age-standardised rates was $11.6 \%$ and $32.3 \%$, respectively. In the female population, a significant increase by $59.2 \%(p<0.05)$ was noted based on crude rates. The non-significant increase of $32.3 \%$ was observed based on age-standardised rate values (Table 1).

Table 1. Lung cancer incidence in Świętokrzyskie Voivodeship in 1999-2013 by sex. Absolute numbers, percentages, and crude and age-standardised rates

\begin{tabular}{|c|c|c|c|c|c|c|c|c|c|c|c|c|}
\hline \multirow[t]{2}{*}{ Year } & \multicolumn{4}{|c|}{ Total } & \multicolumn{4}{|c|}{ Male } & \multicolumn{4}{|c|}{ Female } \\
\hline & $N$ & $C R$ & $A S R$ & \% pop. & $N$ & $C R$ & ASR & \% pop. & $N$ & $C R$ & $A S R$ & \% pop. \\
\hline 1999 & 792 & 59.8 & 39.6 & 0.060 & 678 & 104.3 & 78.4 & 0.104 & 114 & 16.9 & 9.9 & 0.017 \\
\hline 2000 & 817 & 62.7 & 41.0 & 0.063 & 673 & 105.7 & 78.7 & 0.106 & 144 & 21.6 & 11.7 & 0.022 \\
\hline 2001 & 779 & 59.9 & 38.8 & 0.060 & 638 & 100.4 & 73.4 & 0.100 & 141 & 21.2 & 11.7 & 0.021 \\
\hline 2002 & 781 & 60.2 & 38.2 & 0.060 & 659 & 104.0 & 75.0 & 0.104 & 122 & 18.4 & 9.8 & 0.018 \\
\hline 2003 & 709 & 54.8 & 33.7 & 0.055 & 596 & 94.4 & 65.7 & 0.094 & 113 & 17.1 & 9.4 & 0.017 \\
\hline 2004 & 755 & 58.5 & 35.2 & 0.059 & 619 & 98.3 & 66.3 & 0.098 & 136 & 20.6 & 11.4 & 0.021 \\
\hline 2005 & 786 & 61.1 & 37.1 & 0.061 & 643 & 102.4 & 69.5 & 0.102 & 143 & 21.7 & 12.2 & 0.022 \\
\hline 2006 & 799 & 62.3 & 38.0 & 0.062 & 623 & 99.7 & 66.8 & 0.100 & 176 & 26.8 & 15.7 & 0.027 \\
\hline 2007 & 709 & 55.5 & 32.6 & 0.055 & 563 & 90.4 & 59.1 & 0.090 & 146 & 22.3 & 12.4 & 0.022 \\
\hline 2008 & 749 & 58.8 & 33.6 & 0.059 & 600 & 96.7 & 61.9 & 0.097 & 149 & 22.8 & 12.0 & 0.023 \\
\hline 2009 & 763 & 60.0 & 33.2 & 0.060 & 602 & 97.3 & 60.5 & 0.097 & 161 & 24.7 & 12.8 & 0.025 \\
\hline 2010 & 738 & 57.4 & 31.0 & 0.057 & 569 & 90.7 & 55.1 & 0.091 & 169 & 25.7 & 12.6 & 0.026 \\
\hline 2011 & 772 & 60.3 & 33.3 & 0.060 & 593 & 94.8 & 58.3 & 0.095 & 179 & 27.3 & 13.6 & 0.027 \\
\hline 2012 & 722 & 56.6 & 29.8 & 0.057 & 542 & 87.0 & 50.4 & 0.087 & 180 & 27.6 & 13.9 & 0.028 \\
\hline 2013 & 747 & 58.8 & 30.8 & 0.059 & 572 & 92.2 & 53.1 & 0.092 & 175 & 26.9 & 13.1 & 0.027 \\
\hline Total & 11418 & 59.1 & 35.1 & 0.059 & 9170 & 97.3 & 64.5 & 0.097 & 2248 & 22.7 & 12.3 & 0.023 \\
\hline$\Delta$ 1999-2013 & -45 & -1.0 & -8.8 & -0.001 & -106 & -12.1 & -25.3 & -0.012 & 61 & 10.0 & 3.2 & 0.010 \\
\hline Z-statistic & & -0.3 & -4.7 & & & -2.2 & -6.6 & & & 3.9 & 1.8 & \\
\hline$\Delta \%$ & -5.7 & -1.7 & -22.3 & -1.7 & -15.6 & -11.6 & -32.3 & -11.6 & 53.5 & 59.2 & 32.3 & 59.2 \\
\hline
\end{tabular}

$N$-number of new cancer cases, $C R$-crude rate, ASR-age-standardised rate, \% pop. - percentage of population share. 


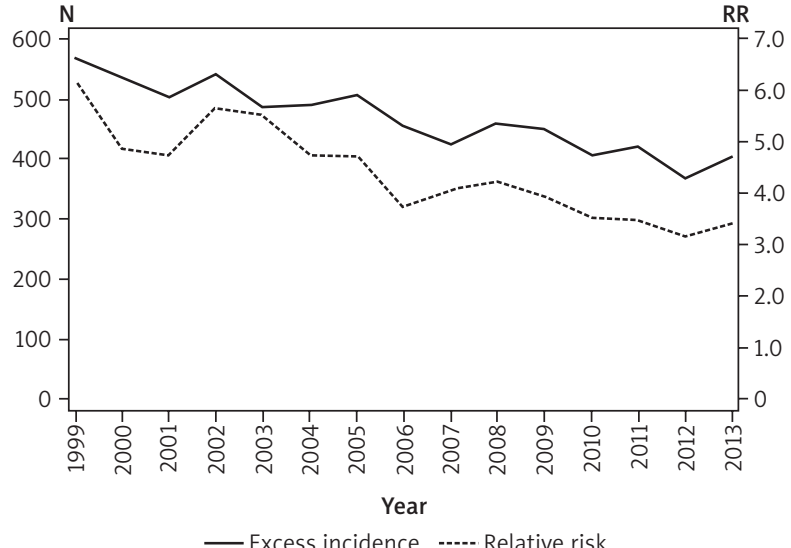

Figure 1. Excess incidence for lung cancer in the male population compared to female population and relative risk in incidence in Świętokrzyskie Voivodeship in 1999-2013

In 2013, compared to 1999 , a decrease of $28.5 \%$ in the Excess incidence was noted in the male population in comparison to the female population $(\Delta=-163)$. The relative risk of lung cancer incidence decreased by $44.5 \%$ in comparison to women $(\Delta=-2.7)$ (Figure 1$)$.
The trend of crude lung cancer incidence rates in Świętokrzyskie Voivodeship from 1999 to 2013 was stable, with non-significant changes in APC. After standardisation, a significant decreasing trend of $2.0 \%$ per year $(p<0.05)$ was observed. Trends in the incidence in male and female populations for both crude and age-standardised rates showed opposite tendencies, allowing us to reject the hypothesis on their parallelism based on the results of the Test for Parallelism. In the male population, trends for crude and age-standardised incidence rates showed a significant decrease by $1.0 \%$ and $2.9 \%(p<0.05)$ per year, respectively. In the female population trends assessed for crude and age-standardised incidence rates showed a significant increase by $3.1 \%$ and $2.1 \%(p<0.05)$ per year, respectively (Table 2, Figures 2 and 3).

\section{Discussion}

Worldwide lung cancer incidence, poor prognosis, and high mortality rate justify continuous research on this malignant cancer. Lung cancer has been the most common type of cancer found in men (1.2 million, $16.7 \%$ of the total) with the highest incidence

Table 2. Trends of lung cancer incidence in Świętokrzyskie Voivodeship in 1999-2013 by sex. Crude and age-standardised rates

\begin{tabular}{|lcccccc|}
\hline Rate & Population & Period & APC & $95 \%$ Cl & $P$-value & $P_{\text {-value* }}$ \\
CR & Total & $1999-2013$ & -0.3 & $-0.6 ; 0.1$ & $>0.05$ & Not applicable \\
ASR & Total & $1999-2013$ & -2.0 & $-2.4 ;-1.5$ & $<0.05$ & \\
CR & Male & $1999-2013$ & -1.0 & $-1.5 ;-0.6$ & $<0.05$ & $<0.05$ \\
\cline { 2 - 5 } & Female & $1999-2013$ & 3.1 & $1.9 ; 4.4$ & $<0.05$ & \\
\cline { 2 - 5 } ASR & Male & $1999-2013$ & -2.9 & $-3.5 ;-2.4$ & $<0.05$ & $<0.05$ \\
& Female & $1999-2013$ & 2.1 & $0.7 ; 3.5$ & $<0.05$ & \\
\hline
\end{tabular}

$C R$-crude rate, $A S R$-age-standardised rate, APC - annual percentage change, $p$-value - significance level for APC, $p$-value ${ }^{*}$ - significance level for Test for Parallelism.
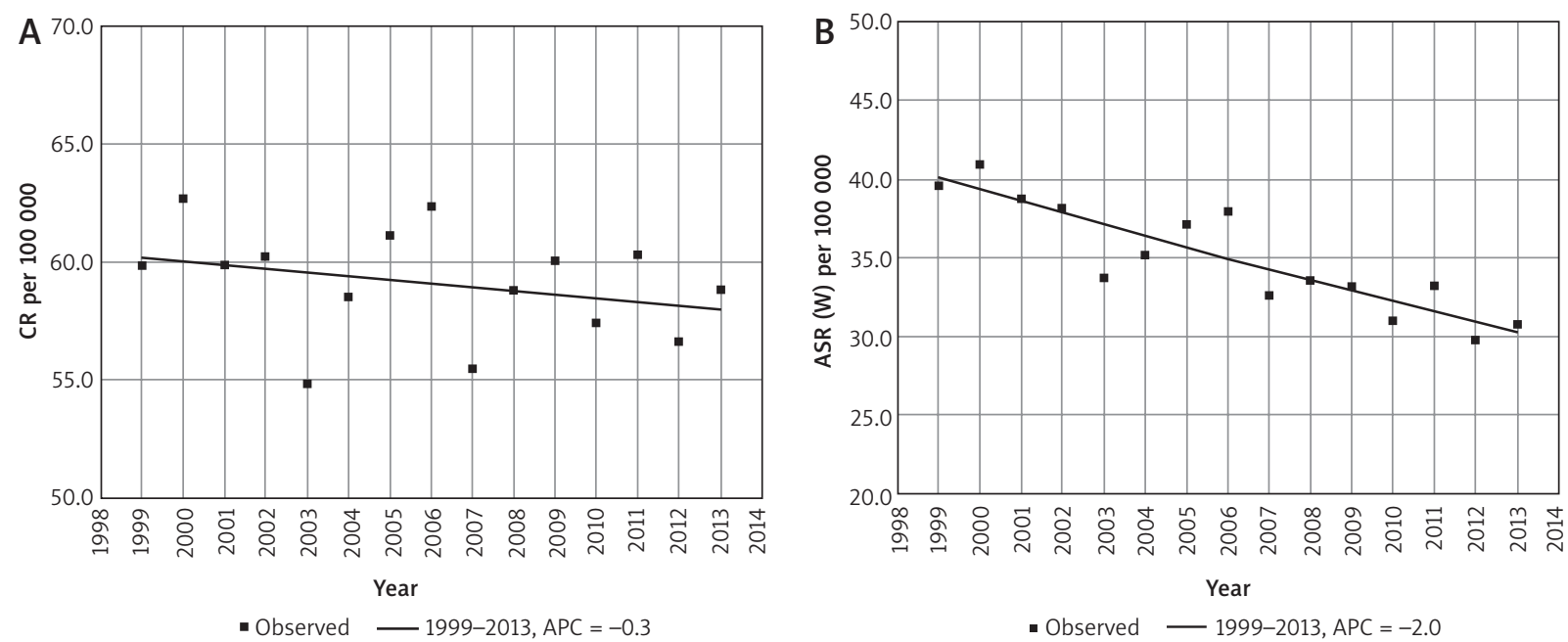

Figure 2. Trends of lung cancer incidence in Świętokrzyskie Voivodeship in 1999-2013: A - crude rates, B - age-standardised rates 

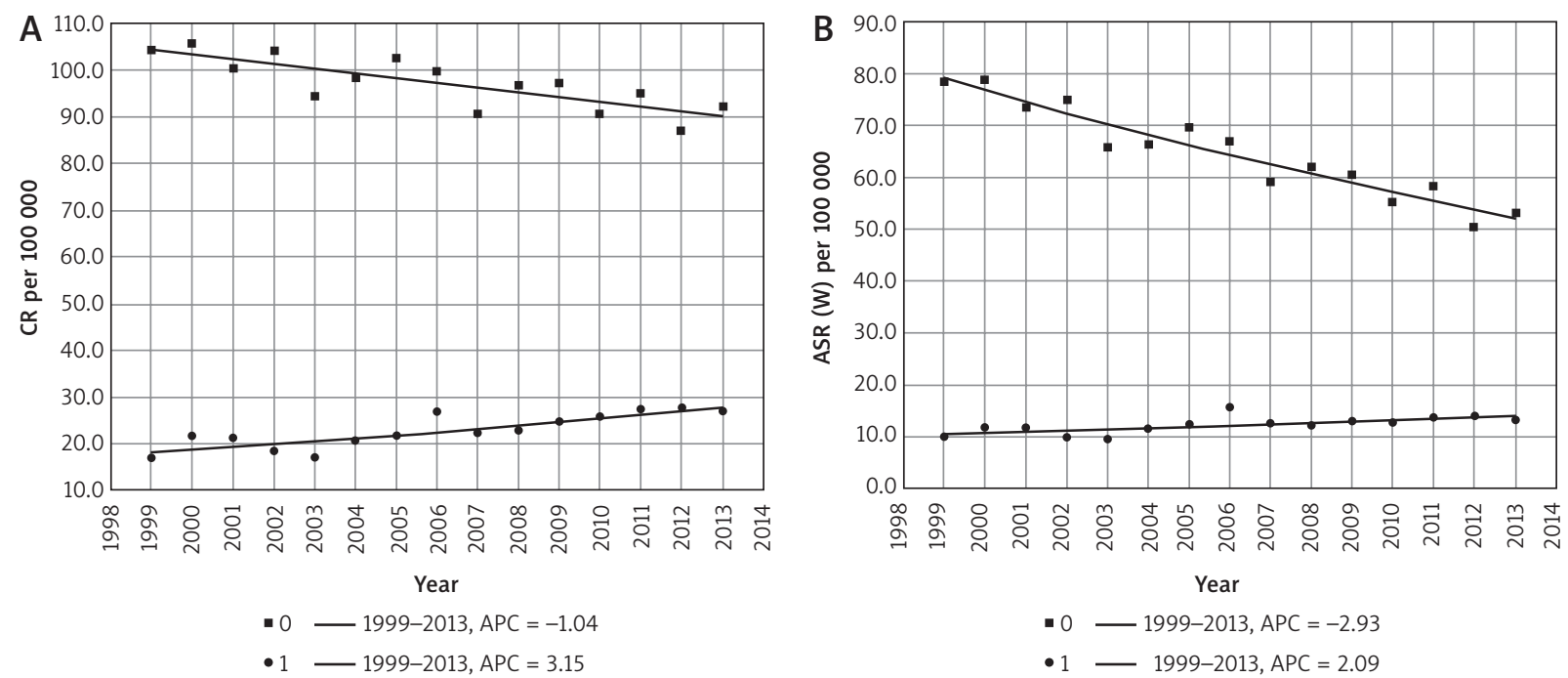

Figure 3. Trends of lung cancer incidence in Świętokrzyskie Voivodeship in 1999-2013 by sex: A - crude rates, B - agestandardised rates; 0 - male, 1 - female

rates in Central and Eastern Europe $\left(53.5 / 10^{5}\right)$ and in Eastern Asia (50.4/105). Lung cancer incidence rates for women are lower in comparison to those found in men [7]. They also show greater geographic differentiation. The highest lung cancer incidence rates are noted in North America $\left(33.8 / 10^{5}\right)$ and in Northern Europe $\left(23.7 / 10^{5}\right)$ and very low in Eastern and Central Africa $\left(1.1 / 10^{5}\right.$ and $0.8 / 10^{5}$, respectively) [2].

Lung cancer is one of the most common cancers present in the cancer profile of Poland. Significant changes in lung cancer incidence among Poles were observed during the period of 15 years (1999-2013). The number of new cases in men decreased by $7.6 \%$, but an increase by $73.6 \%$ in the absolute number of new cases was observed [3].

The direction of these changes conforms to the results of the analysis of changes in absolute number of new lung cancer cases carried out in the analogical period of time among the inhabitants of Świętokrzyskie Voivodeship. The number of new cases in men decreased by $15.3 \%$, in women the increase by $53.5 \%$ was observed. The tendency of the changes discussed above, with their identical directions, differed from the tendency noted in Poland the decrease in the male population was higher and the increase in female was lower compared to the nationwide level. That was reflected in shaping the age-standardised lung cancer incidence rates, which were higher in men from Świętokrzyskie Voivodeship in $1999\left(78.4 / 10^{5} ; 48.1 / 10^{5}\right.$ in Poland) and lower in women in $1999\left(9.9 / 10^{5} ; 12.9 / 10^{5}\right.$ in Poland) as well as in $2013\left(13.1 / 10^{5}\right.$; in Poland $\left.18.3 / 10^{5}\right)$.

These trends are also reflected in the analysis regarding the decrease in Excess incidence with associated decrease of relative risk of lung cancer incidence in the male population in comparison to the female population from Świętokrzyskie Voivodeship. The lung cancer incidence rates have always been higher in men. This is primarily because of the higher smoking rates among men in earlier decades. The reasons for the greater likelihood of developing lung cancer are in general fully understood. Historical higher percentage of smokers among men and greater occupational exposure to carcinogenic compounds, i.e. asbestos, resulted in greater chances of developing lung cancer [8].

Analyses of lung cancer incidence trends carried out for Świętokrzyskie Voivodeship do not differ from results obtained in other studies. The results obtained by the authors of this study are similar to the results of the research carried out in England by Olajide et al. between 2002 and 2011, which showed the decrease of $1.0 \%$ of the age-standardised incidence rate in men per year (compared to $2.9 \%$ in our study) and the increase by $1.9 \%$ in women per year (in our study $2.1 \%$ ) throughout the whole period [9]. Similar results were obtained in the study carried out in North Sardinia (Italy) in the period 1999-2010. The time-trend analysis showed a steady increase in lung cancer incidence rates in women with a slight reduction of lung cancer incidence in men at the same time. These trends correspond to the numerous national and international geographical regions. They may also reflect the increase in diffusion of tobacco smoking among women, with simultaneous reduction of smoking incidence among men [10].

The correlation of smoking with the higher risk of developing lung cancer is the best known and the most frequently cited in literature modifiable risk factor of the disease. The risk of developing lung cancer is above all associated with active or passive exposure to carcinogenic compounds found in tobacco smoke 
[11]. It is estimated that $85-90 \%$ of new lung cancer cases are due to tobacco smoking, and almost a half of new cases among non-smokers is the result of passive smoking [12]. The existence of direct connection between this particular risk factor and the lung cancer incidence was accepted as late as the mid-1960s. It is worth mentioning that in the $20^{\text {th }}$ century tobacco smoking (in particular of cigarettes) was an important part of lifestyle and the greatest health scourge, which changed the image of human diseases and contributed to the premature death of 100 million people [13]. The identification of causality of smoking with the development of lung cancer was possible thanks to the results of studies published in England by Doll \& Hill [14] and in the United States by Hammond [15].

The correlation between decreased incidence levels of lung cancer in men and increased incidence levels in women in Poland is associated with changes in the range of exposure to carcinogenic compounds of tobacco smoke. The frequency of tobacco smoking among men in Poland has been decreasing for two decades in all age groups. The level of smoking among women is differentiated by the cohort effect. The highest percentage of female smokers is observed in the generation of women born between 1940 and 1960, who reached adulthood in 1960-1980. In some periods, the percentage of active smokers among them was up to $50 \%$. In the female population born after 1960 the frequency of smoking is reduced almost by a half and is $20-25 \%$. The risk factor, which is exposure to carcinogenic compounds of tobacco smoke, after taking into consideration the 20-year latency of lung cancer, explains well the present increasing trends in incidence for this malignant cancer in the female population in different age groups over time [16].

The factors that increase the risk of developing lung cancer include those of genetic background as well. The results of the study published in The Lancet Oncology shed a new light on the correlation between tobacco smoking and development of lung cancer, particularly in the group of women. American scientists reported that the disease occurs also in people who have never smoked cigarettes - in 15\% of cases among men and as high as 53\% among women. The scientists associate the cause of the disease with the GPC5 gene, which prevents the development of many cancers. The mutation in the GPC5 gene was detected in many non-smokers with diagnosed lung cancer. The results of the study suggest that the mutation (responsible for the decrease in activity of the GPC5 gene in the group of non-smoking individuals affected with lung cancer) is the cause of lung cancer among non-smoking people [17]. In light of the research published by Clinical Cancer Research, another genetic factor plays an important role in developing lung cancer. The authors analysed samples of genetic material collected from members of multi-generation families, in which five or more people were affected with lung cancer. They showed that the RGS17 gene is related to familial predispositions for lung cancer [18]. The discovery of the impact of these genes for the development of lung cancer may change the diagnostics and treatment methods for this type of cancer, just as the discovery of BRCA1 and BRCA2 genes has changed the diagnostics and treatment of female patients prone to hereditary breast cancer.

The high lung cancer incidence is associated with observed demographic changes (ageing of the society) as well as with the decrease in mortality because of cardiovascular diseases [19]. The most important demographic changes are those related to the age structure of the population, in particular in terms of increasing life span and survival rate. In the case of lung cancer, which is characterised by a long latency period, counted in tens of years since the start of exposure to carcinogenic factor (i.e. starting smoking) until the onset of the disease, the observed changes in demography are significant [20]. The morbidity for this type of malignant cancer is strongly correlated to age - the highest risk is observed in the group at the most advanced age in both sexes [21]. Lung cancer incidence reaches its peak in the sixth and seventh decades of life, both in men and in women, with the subsequent decrease [22]. The increase in lung cancer incidence in the eighth decade of life has been observed in Poland since the 1990s. The tendency of developing the disease in old age is related to the extension of life span in the Polish population [19].

Occupational exposure to carcinogens and air pollution are other recognized factors that increase the risk of developing lung cancer. They are responsible for ca. $9-15 \%$ and $1-2 \%$ of the new cases, respectively. The most well-known factors of confirmed carcinogenic activity are the ones related to occupational exposure. These include asbestos, radon, polycyclic aromatic hydrocarbons, chromium, inorganic arsenic compounds, and ionising radiation [22]. Since 2013, outdoor air pollution and particulate matter in outdoor air pollution are considered by the IARC as carcinogenic to humans as well. The IARC found that exposure to air of poor quality (i.e. with high concentrations of pollutants) or exposure to traffic is associated with increased risk of developing lung cancer [23].

The most important tool nowadays in fighting the incidence and mortality rate due to lung cancer as a result, is the primary prevention, which relies on fighting nicotine addiction - the main cause of lung cancer morbidity. Part of this fight includes a ban on advertising tobacco products and the introduction of a ban on smoking in public spaces. Another important tool allowing the detection of lung cancer at an early stage is the secondary prevention aimed at asymptomatic people belonging to high-risk groups [24]. Screening tests, which are commonly used in early detection of breast, cervical, prostate, and colon cancer, are not a standard procedure in lung cancer 
detection in Poland. Attempts of secondary prevention taking into consideration screening tests with the application of conventional X-ray and cytological tests of the sputum were inefficient (i.e. they did not have an impact on lowering the mortality rate). Promising test results were obtained in the National Lung Cancer Screening Trial (NLCST) in the United States. They showed that low-dose computer tomography (LDCT) of the chest resulted in a decrease in the lung cancer-associated mortality in people from high-risk groups by over $20 \%$ [25]. After the results were published, LDCT was approved in 2011 by the National Cancer Centre in the United States [26]. This method is considered nowadays as the only efficient tool in screening tests for lung cancer. The results obtained during the NLCST trial may become a basis for preparation of lung cancer secondary prevention policy in Poland [27]. However, screening tests must be strictly associated with primary prevention that aims to eradicate the exposure to tobacco smoke and still plays a key role in fighting lung cancer [11].

Dynamic progress of genetics and the more efficient combined treatment raise hope in the fight against the disease [24]. A breakthrough in diagnostics and in the treatment are highly awaited factors towards an efficient fight against lung cancer, which remains the most common and the most dangerous malignant cancer.

\section{Conclusions}

In the period from 1999 to 2013, a decrease by a third in lung cancer incidence was observed in Świętokrzyskie Voivodeship, with the associated decrease in relative risk among men and an increase by over $50 \%$ in incidence among women. Sex also had an impact on shaping the opposed tendencies in incidence trends. A significant decreasing incidence trend among men, with a significant increasing incidence trend among women at the same time, were observed starting from 1999. The results indicate that it is necessary to intensify the primary prevention, particularly in the field of shaping pro-health attitudes among the inhabitants of Świętokrzyskie Voivodeship, and to introduce a program of early detection of lung cancer as a form of secondary prevention.

\section{Conflict of interest}

The authors declare no conflict of interest.

\section{References}

1. Ferlay J, Soerjomataram I, Ervik M, Dikshit R, Eser $S$, Mathers C, Rebelo M, Parkin DM, Forman D, Bray F. GLOBOCAN 2012 v1.0, Cancer Incidence and Mortality Worldwide: IARC CancerBase No. 11 [Internet]. Lyon, France: IARC; 2013 [cited 2016 May 10]. Available from: http://globocan.iarc.fr.
2. Ferlay J, Soerjomataram I, Dikshit R, Eser S, Mathers C, Rebelo M, Parkin DM, Forman D, Bray F. Cancer incidence and mortality worldwide: sources, methods and major patterns in GLOBOCAN 2012: GLOBOCAN 2012. Int J Cancer 2015; 136: E359-86.

3. Raporty Krajowego Rejestru Nowotworów [Internet]. [cited 2015 Mar 20]. Available from: http://onkologia.org.pl/ raporty/.

4. Smok-Kalwat J, Kowalska A, Stępień D, Macek P, Góźdź S. Nowotwory złośliwe $\mathrm{w}$ województwie świętokrzyskim w 2013 roku. Świętokrzyskie Centrum Onkologii, Kielce 2015; 69.

5. Keppel KG, Pearcy JN, Klein RJ. Measuring progress in Healthy People 2010. Healthy People 2010 Stat Notes 2004; 25: 1-16.

6. Hynes MM, Mueller LM, Li H, Amadeo F. Mortality and its Risk Factors in Connecticut, 1989-1998. Appendix II. Glossary. Hartford CT Conn Dep Public Health 2005; 8.

7. Panko S, Karpitski A, Shelepen K, Kazarez M, Vakulich D, Boufalik R, Shestiuk A, Zhurbenka G, Ignatiuk A. Epidemiology, diagnostics and long-term overall survival of patients with non-small cell lung cancer in the Brest Region. Stud Med 2013; 29: 203-12.

8. Wilkins D. Men and Cancer: Saving Lives. Men's Health Forum, London 2013; 58

9. Olajide O, Field J, Davies M, Marcus M. Lung cancer trend in England for the period of 2002 to 2011 and projections of future burden until 2020. Int J Oncol 2015; 47: 739-46.

10. Paliogiannis P, Attene F, Cossu A, Budroni M, Cesaraccio R, Tanda F, Trignano M, Palmieri G. Lung cancer epidemiology in North Sardinia, Italy. Multidiscip Respir Med 2013; 8: 45.

11. Krzakowski M, Jassem J, Dziadziuszko R, Kowalski DM, Olszewski W, Orłowski T, Rzyman W, Smorczewska M. Nowotwory płuca i opłucnej oraz śródpiersia. In: Zalecenia postępowania diagnostyczno-terapeutycznego w nowotworach złośliwych 2013 rok. Krzakowski M, Warzocha K (eds). Vol. I. VM Media Sp z o.o. VM Group sp. k. (Grupa Via Medica), Gdansk 2013; 71-101.

12. Kołodziej J, Marciniak M. Rak płuca. Termedia, Poznan 2010; 248.

13. Zatoński W, Górecka D, Opolski G, Pużyński S, Radziwił K, Ziętek M. Konsensus dotyczący rozpoznawania i leczenia zespołu uzależnienia od tytoniu. Gaz Lek 2008; 216: 1-16.

14. Doll R, Hill AB. The mortality of doctors in relation to their smoking habits. Br Med J 1954; 1: 1451.

15. Hammond EC, Horn D. Smoking and death rates - report on forty-four months of follow-up of 187,783 men. J Am Med Assoc 1958; 166: 1294-308.

16. Zatoński WA, Sulkowska U, Didkowska J. Kilka uwag o epidemiologii nowotworów w Polsce. Nowotw J Oncol 2015; 65: 179-96.

17. Li Y, Sheu CC, Ye Y, de Andrade M, Wang L, Chang SC, Aubry MC, Aakre JA, Allen MS, Chen F, Cunningham JM, Deschamps C, Jiang R, Lin J, Marks RS, Pankratz VS, Su L, Li Y, Sun Z, Tang H, Vasmatzis G, Harris CC, Spitz MR, Jen J, Wang R, Zhang ZF, Christiani DC, Wu X, Yang P. Genetic variants and risk of lung cancer in never smokers: a genome-wide association study. Lancet Oncol 2010; 11: $321-30$

18. Christiani DC. Lung cancer genetics: a family affair? Clin Cancer Res 2009; 15: 2581-2. 
19. Kępka L. Dylematy radykalnego leczenia onkologicznego chorych na raka płuca w okresie starości. Pneumonol Alergol Pol 2009; 77: 166-72.

20. Zatoński W, Sulkowska U, Przewoźniak K, Zatoński M. Epidemiologia nowotworów złośliwych w Polsce. In: Zachorowalność i umieralność na nowotwory a sytuacja demograficzna Polski. Potrykowska A, Strzelecki Z, Szymborski J, Witkowski J (eds). Rządowa Rada Ludnościowa, Warsaw 2014; 30-49.

21. Osińska I, Domagała-Kulawik J. Płukanie oskrzelowo-pęcherzykowe w raku płuca - znaczenie w diagnostyce i ocenie odpowiedzi układu odpornościowego. Postepy Hig Med Dosw (online) 2013; 67: 1119-27.

22. Kosacka M, Jankowska R. Epidemiologia raka płuca. Pneumonol Alergol Pol 2007; 75: 76-80.

23. Loomis D, Grosse Y, Lauby-Secretan B, El Ghissassi F, Bouvard V, Benbrahim-Tallaa L, Guha N, Baan R, Mattock $\mathrm{H}$, Straif K; International Agency for Research on Cancer Monograph Working Group IARC. The carcinogenicity of outdoor air pollution. Lancet Oncol 2013; 14: 1262-3.

24. Rzyman W. Rak płuca. Forum Med Rodz 2008; 2: 407-19.

25. National Lung Screening Trial Research Team, Aberle DR, Adams AM, Berg CD, Black WC, Clapp JD, Fagerstrom RM, Gareen IF, Gatsonis C, Marcus PM, Sicks JD. Reduced lungcancer mortality with low-dose computed tomographic screening. N Engl J Med 2011; 365: 395-409.

26. Chorostowska-Wynimko J, Demkow U, Górski P, Krenke K, Kurzyna M, Kuś J, Langfort R, Maszkowska-Kopij K, Roszkowski-Śliż K, Skorupa W, Sobczyńska-Tomaszewska A, Szołkowska M, Torbicki A. Postępy w pneumonologii w 2012 roku. Pneumonol Alergol Pol 2013; 81: 162-81.

27. Orłowski T. Wczesne wykrywanie raka płuca - rola badań przesiewowych. Pneumonol Alergol Pol 2014; 82: 1-2.

\section{Address for correspondence:}

\section{Paweł Macek MD, PhD}

Department of Epidemiology and Cancer Control

Holycross Cancer Centre

ul. Artwińskiego 3, 25-734 Kielce, Poland

Phone: +48 603161576

E-mail: pawel.macek@gazeta.pl 